\title{
INFLUENCE OF PROCESS OF STRAIGHTENING SHIP HULL STRUCTURE MADE OF 316L STAINLESS STEEL ON CORROSION RESISTANCE AND MECHANICAL PROPERTIES
}

\author{
Jakub Kowalski ${ }^{1}$ \\ Lukasz Licznerski ${ }^{2}$ \\ Milena Supernak-Marczewska ${ }^{1}$ \\ Krzysztof Emilianowicz ${ }^{1}$ \\ ${ }^{1}$ Gdańsk University of Technology, Poland \\ ${ }^{2}$ CRIST S.A., Gdynia, Poland
}

\begin{abstract}
The AISI 316L type steel belongs to the group of chromium-nickel stainless steels. They are determined according to European standards as X2CrNiMo17-12-2 and belong to the group of austenitic stainless steels. Steels of this group are used for elements working in seawater environments, for installations in the chemical, paper, and food, industries, for architectural elements, and many others. The chemical composition of corrosion-resistant austenitic steels provides them with an austenite structure that is stable in a wide temperature range, under appropriate conditions for heating, soaking, and cooling. 316L steel plate was subjected to a technological treatment of hot straightening with an oxyacetylene torch, which is not commonly used for this type of steel, mainly due to the lack of objective assessment of whether the austenitizing temperature has been achieved and the stability of the heat treatment process is ensured. The single-phase structure of austenite with high corrosion resistance, without precipitation of carbides, steel is obtained by supersaturation in water from $1100^{\circ} \mathrm{C}$. The purpose of the presented research was to determine the usefulness of the flame straightening process for a ship structure made of $316 \mathrm{~L}$ steel.
\end{abstract}

Keywords: $316 \mathrm{~L}$ steel, flame straightening, corrosion resistance, mechanical properties

\section{INTRODUCTION}

The technological process of hot straightening of steel is one of the most frequently performed operations in the shipbuilding industry. It is carried out in order to obtain the desired shape of the welded structure by reduction of structural deformations resulting from welding to a specific level that does not exceed the limit values. In the case of structural steels, there are strictly described phenomena that allow for proper hot straightening without undesirable effects on the structure of the material. The heated steel develops tarnish colours that are closely related to the temperature that the material reaches at a given moment, which affects the full control of the process. This allows the process to be carried out without phase changes occurring in the material. In the case of austenitic steels, it is not possible to observe the color change during heating, because austenitic steel does not have intermediate stages, it immediately turns to brown, that makes the proper performance of the process difficult. Nowadays, two main methods of straightening are used in the shipbuilding industry: flame straightening (suitable for carbon steels, due to tarnish colours) and induction (suitable for carbon and austenitic steels as well). During the production of fishing vessels, the Crist shipyard had to deal with the straightening process of structures made from austenitic $316 \mathrm{~L}$ steel. Because the shipyard did not have the possibility of performing straightening construction with induction technology, a trial of flame straightening of austenitic steel was performed.

Compared to ferrite, the effect of alloying elements on austenite is less well known because the stable austenite at room temperature can be achieved by a correspondingly high content of alloying elements $[5,6,9,13,17]$. Alloy austenite has very good plasticity and impact strength and can obtain special properties such as high corrosion resistance, heat resistance, 
creep resistance, and abrasion resistance. The single-phase structure of austenite with high corrosion resistance, without precipitation of carbides, is obtained by steel supersaturation in water at $1100^{\circ} \mathrm{C}$. Reheating the steel to a temperature higher than $500^{\circ} \mathrm{C}$, for example in operating conditions or during welding, is followed by separation of chromium carbide in the form of a grid, often intermittently at grain boundaries in the welding heat affected zone. This process is associated with chromium depletion of areas adjacent to austenite grain boundaries and intergranular corrosion. This phenomenon occurs for austenitic steels with a carbon content equal or greater of $0.03 \%$. The tested steel, according to the point measurement of the chemical composition, showed the values of approximately 0.026 to $0.029 \% \mathrm{C}$, additionally, the surface layer of the steel during the heating process could cause carburization At a temperature of about $500^{\circ} \mathrm{C}$, the $\mathrm{Cr}$ diffusion rate is much lower than the $\mathrm{C}$ diffusion rate. Coal-forming carbides pass from the area of the whole grain, while Cr passes from the areas adjacent to its boundaries This may cause a local decrease in the Cr concentration below about 12\% [2], [5], [12], [15]. For this reason, Flade potential increases rapidly in these places and makes it more sensitive to electrochemical corrosion along grain boundaries. The rate of $\mathrm{Cr}$ diffusion at a temperature of about $650^{\circ} \mathrm{C}$ is much higher than at a lower temperature, and therefore intercrystalline corrosion does not occur after heating to this temperature. This process is strongly related to the carbon content of steel. For steel with $0.01 \% \mathrm{C}$ it should not be present. Similarly, chromium depletion it has a significant prolongation of steel heating, even at a relatively low temperature - close to $500^{\circ} \mathrm{C}$. Sensitivity to intergranular corrosion depends on the carbon concentration in the solution, temperature, and soaking time, as shown in the graph of TTP (time-temperature-precipitation) [4], [7], [17].

Effective prevention is to intergranular corrosion prevention of the separation of chromium carbides, which can be achieved, inter alia, by re-supersaturation of steel, reduction of the $\mathrm{C}$ concentration below $0.03 \%$ and the so-called stabilization of steel by introducing carbide-forming alloying elements with a higher chemical affinity for coal, most often $\mathrm{Ti}$ and $\mathrm{Nb}$, so that permanent MX type carbides are formed and do not pass into the solid solution during supersaturation [20].

The purpose of the research is to determine the usefulness of the flame straightening process in shipbuilding practice, applied to austenitic sheets. Tests were carried out to show what is the impact of the technology used on the mechanical and corrosion properties of the tested material.

\section{MATERIAL}

Tests were carried out on $316 \mathrm{~L}$ steel plates after the flame heating process. The steel plates were austenitic steel, which, due to its corrosion resistance and high plasticity properties, has a wide spectrum of uses. It is commonly used even under cryogenic conditions. In shipbuilding industry it is used to make, among others, LNG gas tanks in a liquid state (operating temperature of about $-155^{\circ} \mathrm{C}$ ), piping and to lay RSW (refrigerated seewater) holds (for transporting fish in water at a temperature close to $0^{\circ} \mathrm{C}$ ) of fishing vessels (see Fig. 1).

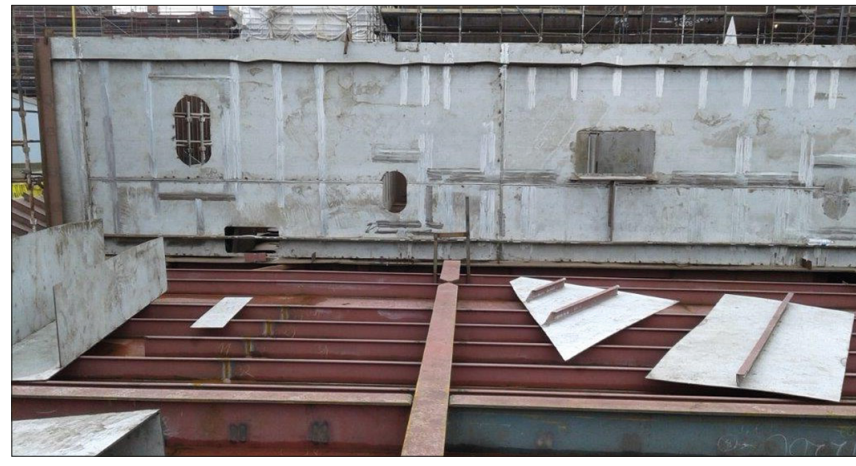

Fig. 1. RSW cargo tank under construction in shipyard

Eight test plates were provided for testing: two reference ones made of material not subjected to flame straightening (reference material), three straightened and naturally cooled ones), and three straightened and water-cooled ones (All panels had dimensions of $300 \times 450 \mathrm{~mm}$ and a thickness of $10 \mathrm{~mm}$. Straightening was carried out using triple flame burners. Figure 2 shows the plate during straightening. The straightening direction was perpendicular to the rolling direction.

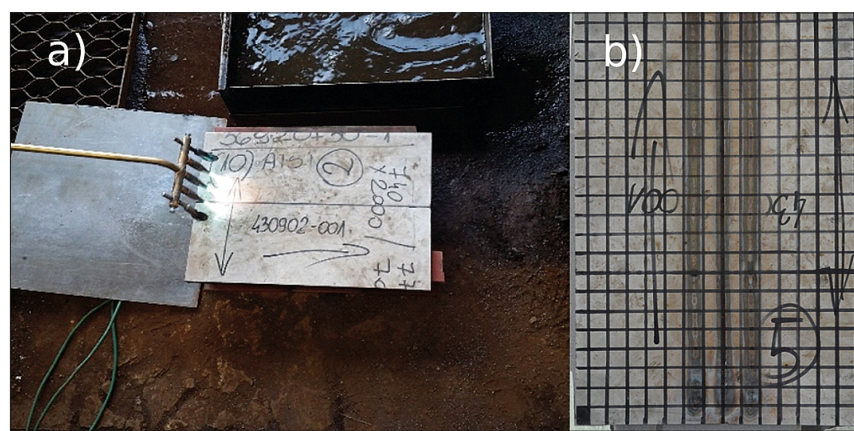

Fig. 2. Test plate during straightening process (a) and surface after process (b)

Tab. 1.Chemical composition of tested steel (in wt. \%)

\begin{tabular}{|c|c|c|c|c|c|c|c|c|c|c|c|}
\hline & $\mathrm{C}$ & $\mathrm{Mn}$ & $\mathrm{Si}$ & $\mathrm{P}$ & S & $\mathrm{Cr}$ & $\mathrm{Ni}$ & Mo & $\mathrm{N}$ & $\mathrm{Cu}$ & Co \\
\hline Reference material & 0.029 & 1.42 & 0.46 & 0.027 & $<0.002$ & 16.71 & 10.57 & 1.92 & - & 0.42 & 0.24 \\
\hline Natural cooling & 0.026 & 1.67 & 0.42 & 0.011 & 0.005 & 17.14 & 10.81 & 1.96 & - & 0.07 & 0.04 \\
\hline Water cooling & 0.028 & 1.67 & 0.42 & 0.009 & 0.003 & 17.13 & 10.85 & 1.95 & - & 0.07 & 0.03 \\
\hline \multicolumn{12}{|c|}{ Reference values according to 1.4404 (PN-EN 10088-1) / AISI 316L } \\
\hline
\end{tabular}




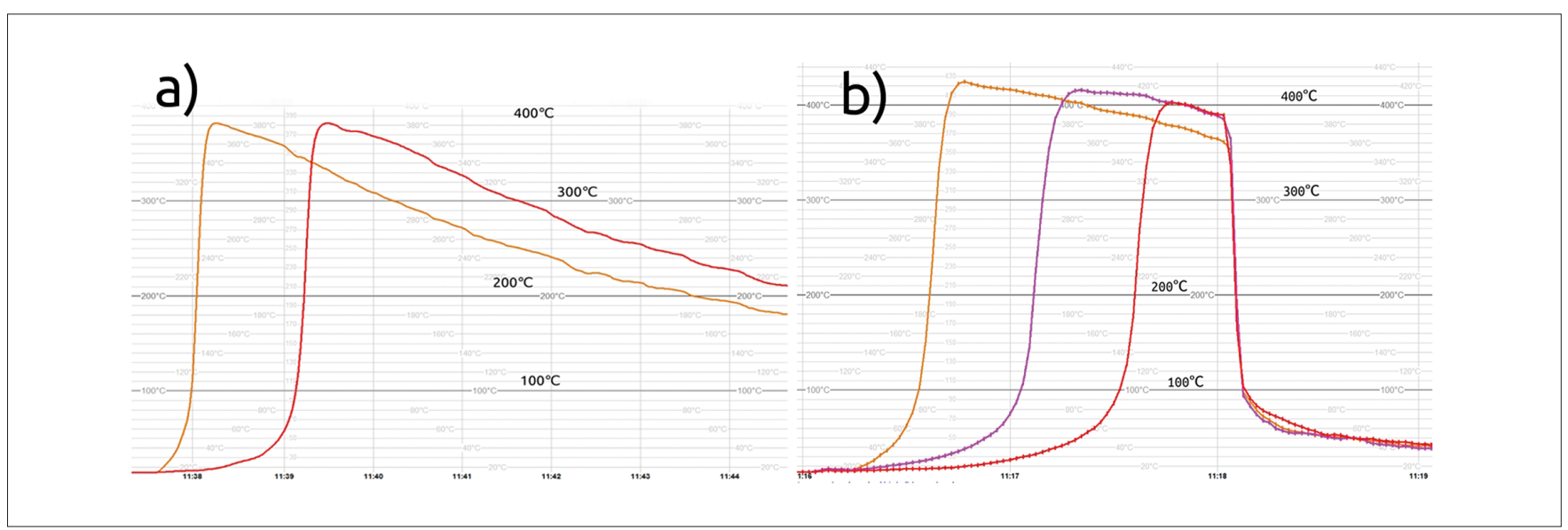

Fig. 3. Temperature record during cooling: a) natural, b) rapid (water bath)

Chemical composition testing was carried out and the results are summarized in Table 1. A Spectrolab M5 optical spectrometer was used for the tests. Each specimen was checked five times. Presented values are averaged.

In order to control the temperature during both heating and cooling, thermocouple sensors are mounted on each of the plates. The process record is shown in Fig. 3a for natural cooling and in Fig. 3b for rapid water cooling.

From the records of the temperature during the test it is clearly seen that the time required for natural cooling is many times longer than that required for cooling in a water bath. According to the record, during heating, in both cases, the temperature of the plate oscillated around $400^{\circ} \mathrm{C}$. It should be noted that, for technical reasons, the temperature was measured on the side opposite to the heated side of the sheet. After the process was completed, clear plastic deformation (bending) appeared on the metal sheet in a form corresponding to the method of introducing heat into the sheet.

\section{SCOPE OF TESTS, RESULTS, AND DISCUSSION}

Mechanical, macro- and microscopic, and corrosion tests were carried out. To determine the scope of the mechanical tests, similarly to qualification of welded joints, the standard [10] was used. Figure 4a shows the distribution of the samples on the test plate. When planning the distribution of samples on the test plate, the direction of run of the flame was taken into account. All the samples were prepared by machining.

\section{THE TENSILE TEST}

A tensile test was carried out for all three groups of the test plates. For the reference material, the aim was to determine the basic mechanical properties of the tested steel. One specimen for each case was prepared. For the samples after the straightening process, the tensile test was performed to show whether the straightening traces, visible in Fig. 2b, would have different properties. The test was carried out on a ZD40Pu testing machine according to $[11,14]$. Table 2 summarizes

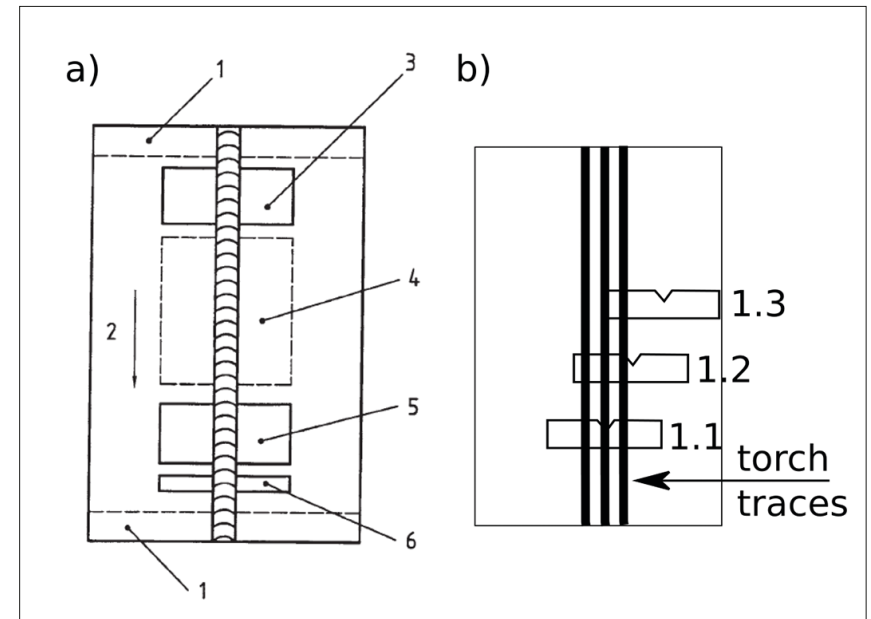

Fig. 4a). Typical test plate for butt weld qualification [11]

1 - to be discarded; 2 - welding direction; 3 - one flat tensile, one face bend, and one root bend specimen; 4 -Charpy V-notch specimens; 5 - one flat tensile, one face bend, and one root bend specimen; 6 - macroscopic and Vickers hardness specimens; b) Charpy V-notch specimen localization schema

the mechanical properties of the reference material. The test was performed both along and across the rolling direction. The differences in mechanical properties are clearly visible: the longitudinal direction is characterized by about $7 \%$ higher plasticity and about $4 \%$ lower strength limit. For tensile test uncertainty of measurements was estimated in accordance to [10]. For tensile and proof strength combined uncertainty is equal to $0.27 \%, 0.014 \%$ for elongation after fracture.

Tab. 2. Tensile properties of reference steel. $L$ - specimen parallel to rolling direction; $T$ - specimen transverse to rolling direction

\begin{tabular}{|c|c|c|c|c|c|c|}
\hline & $\begin{array}{c}\text { Dimen- } \\
\text { sions, } \mathrm{mm}\end{array}$ & $\begin{array}{c}\text { Section } \\
\text { area, } \\
\mathrm{mm}^{2}\end{array}$ & $\begin{array}{c}\text { Initial } \\
\text { length } \\
\mathrm{L}_{0}, \mathrm{~mm}\end{array}$ & $\begin{array}{c}\text { Elonga- } \\
\text { tion after } \\
\text { fracture }\end{array}$ & $\begin{array}{c}\text { Proof } \\
\text { strength } \\
\mathrm{R}_{\mathrm{p} 02} \mathrm{~m}^{2} \\
\mathrm{~N} / \mathrm{mm}^{2}\end{array}$ & $\begin{array}{c}\text { Tensile } \\
\text { strength } \\
\mathrm{R}_{\mathrm{m}} \\
\mathrm{N} / \mathrm{mm}^{2}\end{array}$ \\
\hline $\mathrm{L}$ & $25.00 \times 10.10$ & 253 & 90 & 55 & 317 & 582 \\
\hline $\mathrm{T}$ & $24.90 \times 10.10$ & 251 & 90 & 51 & 315 & 608 \\
\hline
\end{tabular}

Table 3 summarizes the results of the tensile test for the straightened plates. For both heating cases, the strength was basically the same but slightly higher than in the longitudinal direction of the reference plate. Breakage clearly occurred in the zone after passing the burner or at its border. 
Tab. 3. Tensile properties of naturally and water cooled test plates

\begin{tabular}{|c|c|c|c|c|}
\hline $\begin{array}{c}\text { Specimen } \\
\text { designa- } \\
\text { tion }\end{array}$ & $\begin{array}{c}\text { Dimen- } \\
\text { sions, } \mathrm{mm}\end{array}$ & $\begin{array}{c}\text { Section } \\
\text { area, } \\
\mathrm{mm}^{2}\end{array}$ & $\begin{array}{c}\text { Tensile } \\
\text { strength } \\
\mathrm{R}_{\mathrm{m}} \\
\mathrm{N} / \mathrm{mm}^{2}\end{array}$ & Fracture \\
\hline \multicolumn{5}{|c|}{ Naturally cooled } \\
\hline 1.1 & $24.80 \times 10.70$ & 265 & 584 & Heat affected zone \\
\hline 1.2 & $25.10 \times 10.70$ & 269 & 585 & $\begin{array}{c}\text { Fusion line: heat } \\
\text { affected zone / } \\
\text { unaffected material }\end{array}$ \\
\hline 2.1 & $25.10 \times 10.75$ & 270 & 586 & \begin{tabular}{c} 
Heat affected zone \\
\hline 2.2
\end{tabular} \\
\hline
\end{tabular}

\section{THE IMPACT TEST}

Another test whose results are of key importance from the point of view of allowing technology to be used is the impact test. Due to the natural high ductility of the material, the experiment was performed at liquid nitrogen temperature (about $-194^{\circ} \mathrm{C}$ ). Figure $4 \mathrm{~b}$ schematically shows the locations of the Charpy specimens.

An analogy to the procedure contained in the already mentioned standard [8-10] can be seen. The test was carried out for three zones: zones after the burner passage, the transition zone (equivalent to the fusion line), and material unchanged by heat introduced during the process. Similarly to the tensile test was performed for the reference material. The test was carried out in accordance with the standard [16] on samples with a reduced thickness of $7.5 \mathrm{~mm}$. Extended uncertainty of impact test, calculated in accordance to [9] is equal to $7.5 \mathrm{~J}$.

Tab. 4. Impact test results

\begin{tabular}{|c|c|c|c|c|}
\hline \multirow{2}{*}{ Designation } & \multicolumn{5}{|c|}{ Absorbed energy $\mathrm{KV}_{2}, \mathrm{~J}$} \\
\cline { 2 - 5 } & 1 & 2 & 3 & Average \\
\hline \multicolumn{5}{|c|}{ Reference material } \\
\hline Longitudinal & 192 & 188 & 196 & 192 \\
\hline Transverse & 167 & 137 & 131 & 145 \\
\hline \multicolumn{5}{|c|}{ Naturally cooled } \\
\hline 1.1. & 206 & 198 & 198 & 201 \\
\hline 1.2. & 210 & 186 & 204 & 200 \\
\hline 1.3. & 202 & 209 & 190 & 200 \\
\hline \multicolumn{5}{|c|}{} \\
\hline 2.1. & 204 & 208 & 214 & 209 \\
\hline 2.2. & 216 & 216 & 212 & 215 \\
\hline 2.3. & 206 & 218 & 218 & 214 \\
\hline
\end{tabular}

Table 4 lists the results obtained during the impact test. They clearly show that overheating of the material increases the impact strength. The most noticeable increase can be observed in the case of heated and then rapidly cooled sheets.
A change in mechanical properties, such as impact strength, indicates a change in microstructure.

\section{THE HARDNESS TESTS}

Continuing the methodology contained in the standard [6, 10], hardness tests were performed. The purpose of this test was to observe the change in hardness in the rectified region. The measurements were carried out both on the surface, using a standardized test method [21], and on a cross-section. In the second case, the method described in [3] was used. Both types of tests were carried out on a Vickers-Brinell HPO-250 hardness tester. Figure 5 shows the location of the indentions appropriate for the surface Brinell test and the test results.

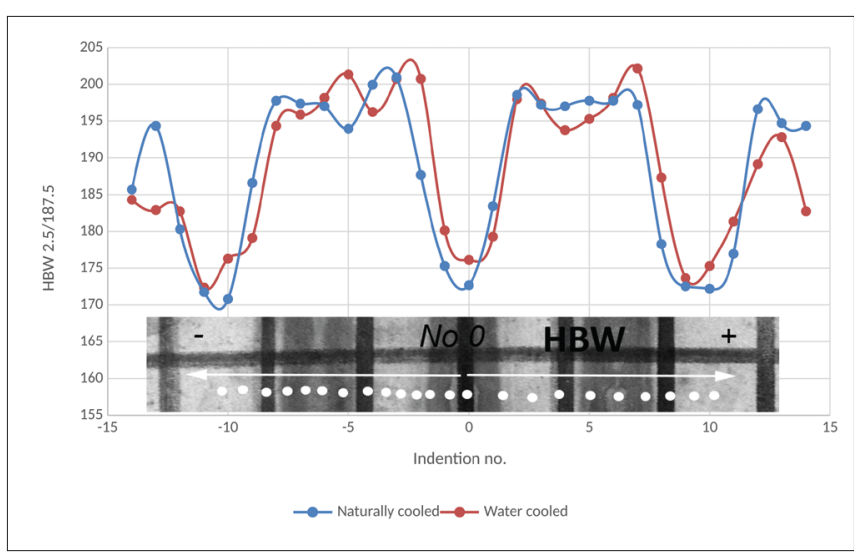

Fig. 5. Surface hardness measurement test result

As can be clearly seen in Fig. 5, the hardness distribution on the surface of the tested objects is heterogeneous and is similar in both cases. It is clearly seen that the lowest hardness values can be found at the points $-10,0$, and 10 . These are measuring points that coincide with the marks after the burner passes. The increase in hardness occurs between the tracks, that is, in places where there was no direct impact of the heat source. The hardness distribution in the tested panels therefore resembles the hardness distribution in the welded joint, where there is a clear increase in hardness in the heat affected zone (on the fusion line), that is, in a place where the heat source did not work directly.

To determine whether the observed changes in the hardness distribution are purely surface in nature, a cross-sectional study was performed. Two measuring lines were made for each case. For the line marked "L", the measurement was made at a depth of about $1 \mathrm{~mm}$ from the heated surface of the test plates, and the measuring points were numbered and arranged as for a surface test. For the line marked "T", the measurement was made according to the material thickness, with measuring points spaced approximately every $1 \mathrm{~mm}$. The measurement lines and test results are depicted in Fig. 6.

As can be seen in Fig. 6, the hardness values measured 1 $\mathrm{mm}$ under the heated surface of the sheet show significantly lower fluctuations. The nature of the graph caused the results to be averaged, and the standard deviation was calculated. For the naturally cooled sheets, the average hardness was $186.5 \pm 2.0 \mathrm{HV} 10$, while for the water-cooled sheets it was 


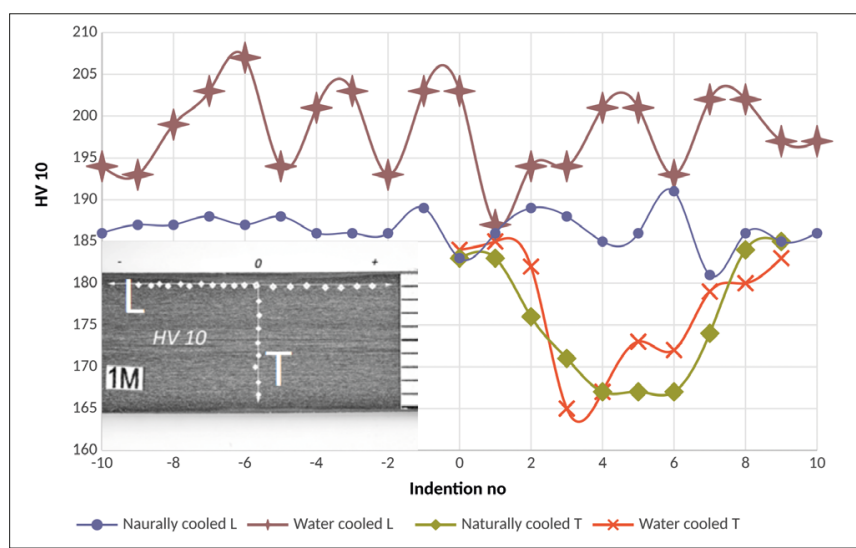

Fig. 6. Vickers hardness test results

$198.0 \pm 4.8 \mathrm{HV} 10$. Analysing the T lines, in both cases, one can notice a certain regularity - the hardness reaches higher values at the material surfaces. This is the result of metallurgical processes - rolling and the effect of the greater pressure on the surface of the sheet (compared to its interior). For sheets cooled after straightening in a natural way, the hardness distribution over the sheet thickness is practically symmetrical. In the case of test plates cooled in a water bath, the effect of the thermal process is clearly visible - the hardness distribution is asymmetrical and its minimum is clearly shifted towards the heated surface.

In parallel to the mechanical tests, macroscopic and microscopic tests were performed, both classical and by using a JEOL JSM-7600F scanning electron microscopy (SEM) equipped with a chemical composition analysis adapter (EDS). Microstructure tests were performed for the specimens: reference, after natural cooling and after cooling in water. Each time the analysis was performed in two areas: austenite and $\delta$-ferrite. Results of the SEM investigation are presented on figure 7 . Table 5 contains chemical composite in investigated areas (in \%at). The micro-sections were digested in accordance with the recommendations contained in [19]. The microscopic tests showed no anomalies in the microstructure or composition.

Table 5. Chemical composition of invastigaded specimens (EDS result)

\begin{tabular}{|c|c|c|c|c|c|c|}
\hline \multirow[b]{2}{*}{ 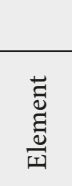 } & \multicolumn{2}{|c|}{ Referece material } & \multicolumn{2}{|c|}{ Naturally cooled } & \multicolumn{2}{|c|}{ Water cooled } \\
\hline & 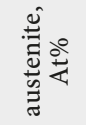 & 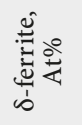 & 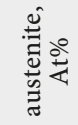 & 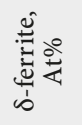 & 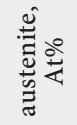 & 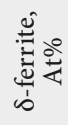 \\
\hline $\mathrm{SiK}$ & 1.12 & 1.29 & 1.08 & 1.13 & 1.02 & 1.10 \\
\hline PK & & 0.22 & & 0.12 & & 0.09 \\
\hline MoL & 1.28 & 2.32 & 1.25 & 2.40 & 1.30 & 2.45 \\
\hline CrK & 18.56 & 24.22 & 18.57 & 25.23 & 18.80 & 25.55 \\
\hline $\mathrm{MnK}$ & 1.38 & 1.12 & 1.63 & 1.21 & 1.58 & 1.26 \\
\hline $\mathrm{FeK}$ & 68.08 & 65.94 & 67.04 & 64.96 & 67.10 & 64.91 \\
\hline $\mathrm{NiK}$ & 9.58 & 4.90 & 10.44 & 4.94 & 10.20 & 4.65 \\
\hline
\end{tabular}

The $\delta$-ferrite content was determined and was about $6.5 \%$ in all cases, which is typical for $316 \mathrm{~L}$ steel [1], so the thermal processes carried out did not affect the microstructure of the tested material. In either case, the steel has an austenitic structure with a small amount of $\delta$ - ferrite. The structure conforms to the steel grade.
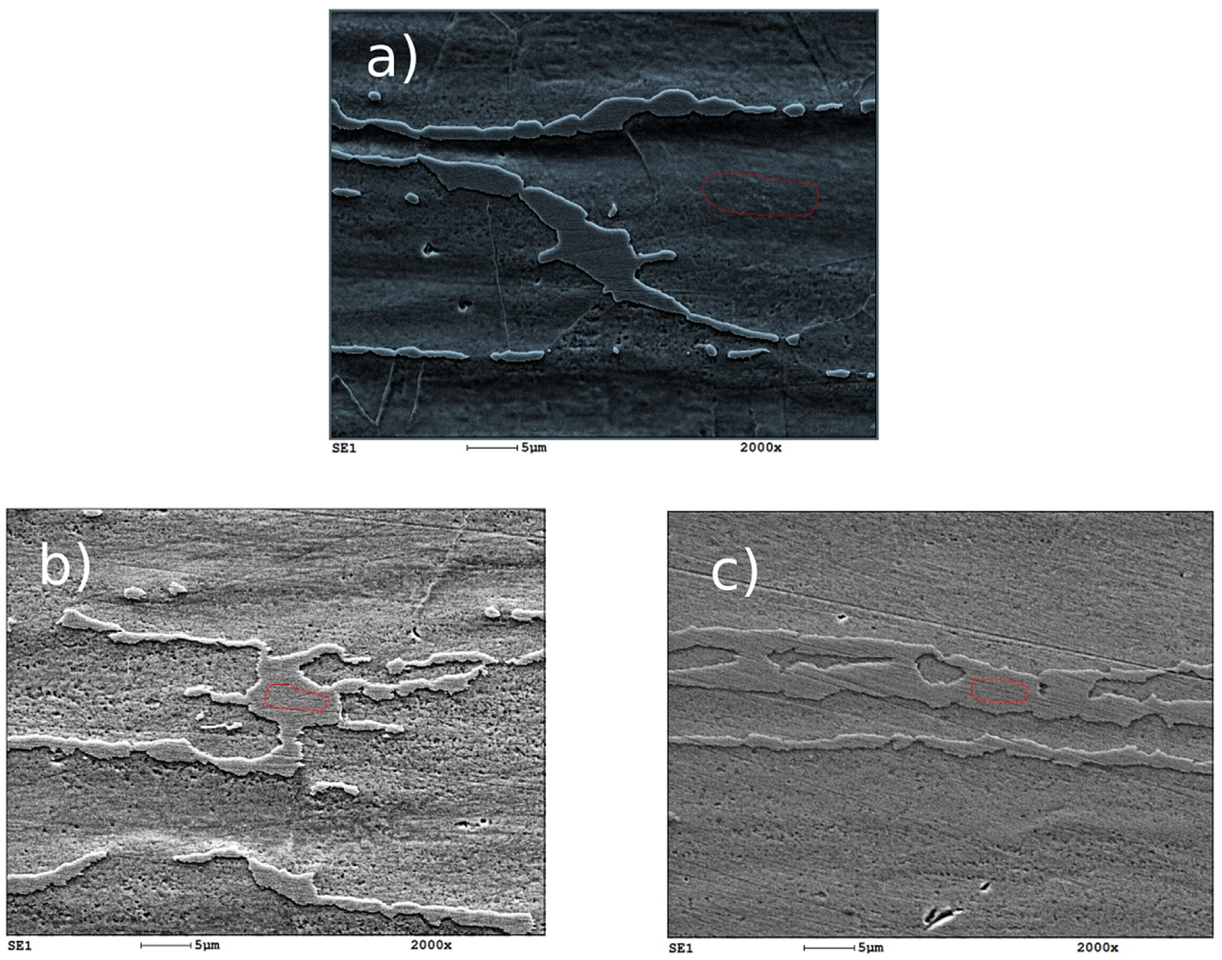

Fig. 7. Result of SEM investigation: a) reference material; b) naturally cooled material; c)water cooled material 


\section{CORROSION TESTS}

In order to determine the impact of the flame straightening process on the corrosion properties, tests were conducted for the presence of intergranular corrosion and resistance to pitting and crevice corrosion. Standardized procedures described in PN-EN ISO 3651-2:2004 [4] and ASTM G48 [1] were used. The dimensions of the samples for the corrosion tests were set as $20 \times 60 \mathrm{~mm}$, while the thickness was equal to $6 \mathrm{~mm}$. Samples were taken from the area subjected to heating. They were positioned in relation to the test plates in such a way that the surface heated by the burner was intact in the process of their preparation and the longer dimension of the samples was perpendicular to the direction of heating of the plate.

The Moneypenny-Strauss test was performed as a test of intergranular corrosion. The previously prepared samples were first degreased, weighed, and placed in a flask on the particles layer consisting of the electrolytic copper material and filled with a corrosive solution (aqueous solution of $16 \%$ sulphuric acid and copper(II)-sulfate). The measuring equipment consisting of a solution flask, reflux condenser, and the heating platform was assembled. Then the prepared set was brought to boiling point and left for about 21 hours. After completion, the samples were removed, rinsed, dried, and reweighed and then subjected to a bending test on a testing machine. The result of the intergranular corrosion test was negative - no intergranular corrosion was found. The tested steel is characterized by its low carbon content, not exceeding $0.03 \% \mathrm{C}$ in the alloy (see Table 1), and thus the obtained result was as expected.

Very interesting results were obtained for the other corrosion tests, especially for the pitting corrosion. The test was carried out in accordance with the standard [4] methods A and B. Before the test was carried out, the specimens were weighed (with 0.001 g accuracy) and degreased with ethanol. Then they were placed in previously prepared flasks: on glass cradles in the case of method $\mathrm{A}$ and on rubber pads in the case of method $B$. In addition, in method $\mathrm{B}$, rings made of Teflon were used, fastened to both side faces of the samples with an elastic band. After preparation, specimens were flooded with a corrosive solution (iron chloride). The test temperature according to the standard was within $22-24^{\circ} \mathrm{C}$. The exposure time was 72 hours. After completion of the test, the samples were removed from the flasks, thoroughly dried, gently scraped with a brush (to remove the loose corrosion products), and accurately weighed again. Surface of each specimen was examinated by Keyence VHX 7000 digital microscope, with $0.01 \mu \mathrm{m}$ resolution. $20 \times$ magnification was used in each case. Corroded area was determined with Keyence software. The results are summarized in Table 6.

Similarly to the tensile strength test, for comparative purposes, the reference material tests were performed. As a result of the observations, a concentration of pits in the area of the burner passage was noticed. The phenomenon is particularly visible for the naturally cooled sheets. For the
Tab. 6. Results of pitting and crevice corrosion tests

\begin{tabular}{|c|c|c|c|c|}
\hline & $\begin{array}{l}\text { चี } \\
\text { हु } \\
\text { कू }\end{array}$ & 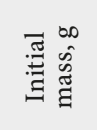 & 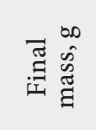 & 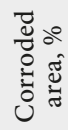 \\
\hline \multicolumn{5}{|c|}{ Pitting corrosion } \\
\hline \multirow{2}{*}{$\begin{array}{l}\text { Reference } \\
\text { material }\end{array}$} & WT_1 & 55.992 & 54.139 & 4.80 \\
\hline & WL_1 & 55.281 & 53.431 & 4.53 \\
\hline \multirow{3}{*}{$\begin{array}{l}\text { Naturally } \\
\text { cooled } \\
\text { material }\end{array}$} & 6.10 & 54.727 & 52.170 & 5.06 \\
\hline & 6.12 & 54.066 & 51.978 & 6.23 \\
\hline & 6.13 & 52.900 & 50.585 & 6.02 \\
\hline \multirow{3}{*}{$\begin{array}{l}\text { Water } \\
\text { cooled } \\
\text { material }\end{array}$} & 3.8 & 53.630 & 51.338 & 11.48 \\
\hline & 3.10 & 51.911 & 49.876 & 8.36 \\
\hline & 3.11 & 51.627 & 49.325 & 10.17 \\
\hline \multicolumn{5}{|c|}{ Crevice corrosion } \\
\hline \multirow{2}{*}{$\begin{array}{c}\text { Reference } \\
\text { material }\end{array}$} & WT_2 & 56.263 & 54.958 & 0.58 \\
\hline & WL_2 & 55.493 & 54.212 & 0.65 \\
\hline \multirow{3}{*}{$\begin{array}{l}\text { Naturally } \\
\text { cooled } \\
\text { material }\end{array}$} & 6.11 & 53.345 & 52.203 & 3.33 \\
\hline & 6.14 & 54.452 & 53.196 & 2.19 \\
\hline & 6.15 & 53.554 & 52.144 & 1.51 \\
\hline \multirow{3}{*}{$\begin{array}{l}\text { Water } \\
\text { cooled } \\
\text { material }\end{array}$} & 3.6 & 53.304 & 52.047 & 8.70 \\
\hline & 3.7 & 53.440 & 52.123 & 11.39 \\
\hline & 3.9 & 50.714 & 49.483 & 13.13 \\
\hline
\end{tabular}

reference samples, the obtained pitting corrosion distributions are shown in Fig. 8. All images of corroded specimens were taken with Nikon D7100 camera with macro photography lens (focal length equal to $60 \mathrm{~mm}$ ).

The crevice corrosion appeared on both the surface and the contact with the rubber and the ring. Images of the tested samples are shown in Fig. 9.

With regard to crevice corrosion, the corroded area, expressed in percent, is different for each case. Average values

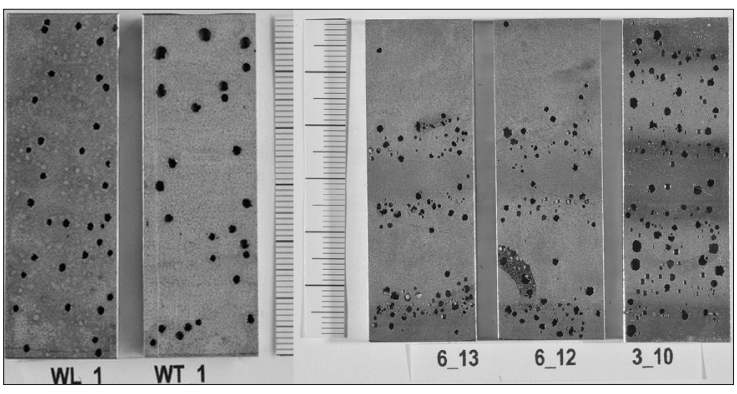

Fig. 8. Pitting corrosion

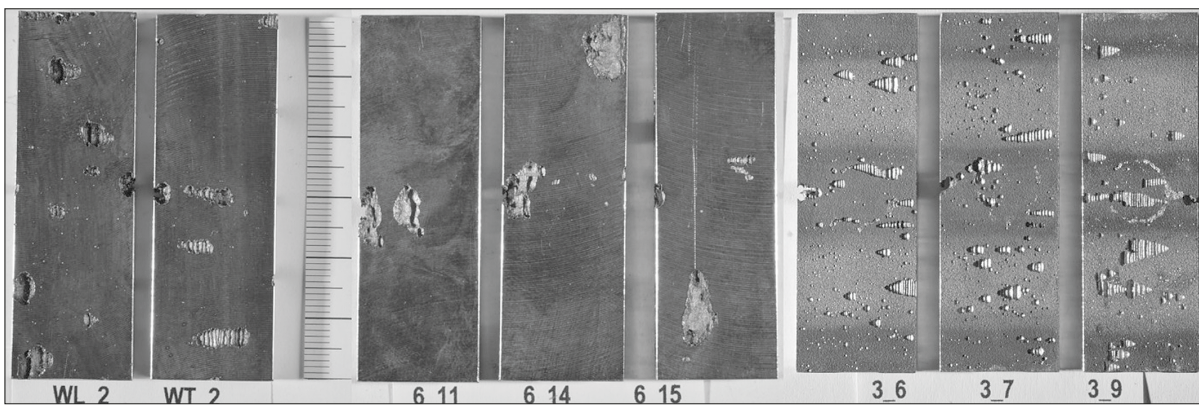

Fig. 9. Crevice corrosion 


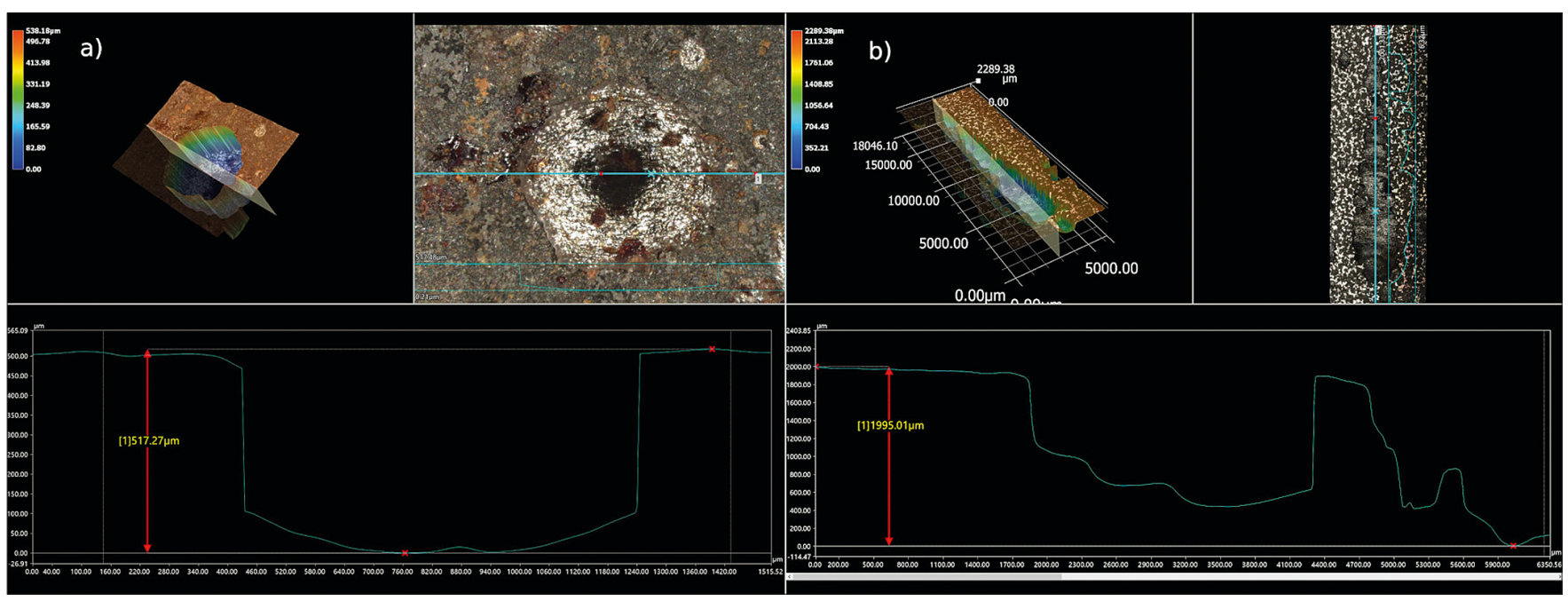

Fig. 10. a) Profile and depths of the smallest observed pits; b) The depths of the largest pits formed during the test; Keyence VHX 7000

for reference material, naturally cooled plates and watercooled plates as sequentially: $0.62 \%, 2.76 \%$ and $10.07 \%$. It can be clearly seen, that there is impact of flame straightening process on crevice corrosion. Pitting corrosion also affected larger area in case of processed plates. It is minor influence when reference material and naturally cooled plates are compared, $4.7 \%$ to $5.8 \%$ of corroded area. In comparison of reference material and water-cooled plate, the difference is over two times $(4.7 \%$ to $10.0 \%$ of corroded area). Moreover, it case of pitting corrosion it can be seen, that pits are concentrated between traces of torch. For reference material, corrosion pits are located evenly.

A significant impact on the emerging corrosion, both pitting and crevice, may be due to the fact that the pretreatment of steel made of $316 \mathrm{~L}$ alloy was carried out together with carbon steel, which is wrong, since the dust deposited on the surface of stainless steel may create additional corrosion centres and as consequence, can affect its increased range of corroded area (shown in Table 6).

It is also worth noting the large dispersion of the size of pits formed during the experiment. For example, for sample No. 3.7 (shown in Fig. 9), it ranges between 0.5 and $2 \mathrm{~mm}$, which is already classified as severe pitting corrosion according to the standard [1]. As shown in Fig. 10a, the smallest pit is $517 \mu \mathrm{m}$ deep and the largest about $1995 \mu \mathrm{m}$. There are also significant differences in the surface profile of the pits. The smallest ones are close to a spherical shape and their longest diameter is about $610 \mu \mathrm{m}$. The largest ones, as seen in Fig. 10b, are oblong and consist of several pits combined with each other, with a total length of about $16850 \mu \mathrm{m}$.

\section{SUMMARY AND CONCLUSIONS}

The research presented in this paper has shown that the flame straightening process has no negative impact on the mechanical properties of the material. Micro- and macroscopic examinations did not show clear changes in the structure of the material as a result of heating with a burner. The ferrite- $\delta$ content is similar in each case and is typical for the tested material. The method of cooling does not affect the internal structure of the material. These observations also indicate that the straightening process took place at temperatures below $1000^{\circ} \mathrm{C}$, as it had no effect on the structural change. The conducted corrosion tests indicate, however, a clear increase in the pitting corrosion rate for plates heated by the burner compared to the corrosion rate of the reference material. The concentration of corrosive pitting was observed at the junction of the burner trace and the "unchanged" material (see Fig. 11).

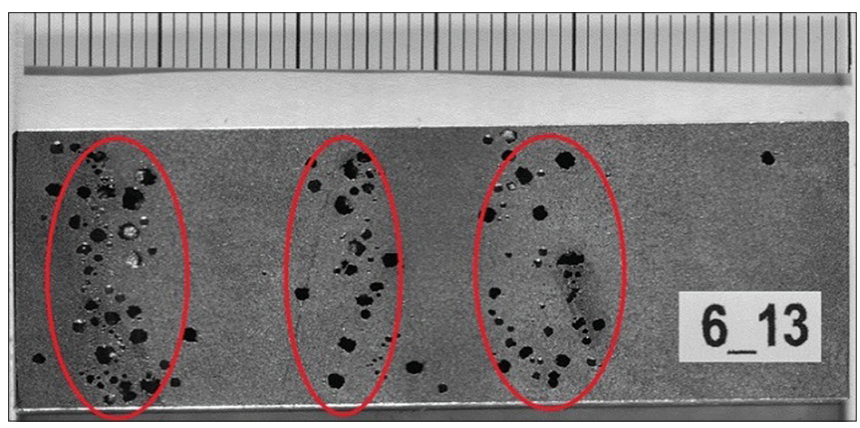

Fig. 11. Pitting corrosion concentration regions

This indicates that the flame straightening process was carried out at a temperature above $500^{\circ} \mathrm{C}$, which led to the phenomenon of dechromination of areas adjacent to the austenite grain boundaries. When heating steel to a temperature higher than about $500^{\circ} \mathrm{C}$, the diffusion rate of $\mathrm{Cr}$ is less than that of $\mathrm{C}$; this process was described in the initial part of the publication.

Austenitic steels constitute about two-thirds of all corrosion-resistant steel production. Technological processes as well as surface treatment appropriate to such a widely used group of engineering materials should guarantee full control of not only of their preparation process but also the properties of the material itself. The process of flame straightening austenitic steels with an acetylene burner does not provide an assessment of the temperature reached by the austenitic steel during the straightening process. 
Due to the high risk of exceeding the safe temperature at which the chromium depletion process of steel occurs, flame-straightening of a structure made of austenitic steel is not recommended to. Induction straightening is definitely a better solution, allowing better control of thermal process parameters in relation to flame straightening.

\section{REFERENCES}

1. ASTM. (2003): ASTM G48-03, Standard Test Methods for Pitting and Crevice Corrosion Resistance of Stainless Steels and Related Alloys by Use of Ferric Chloride Solution. ASTM International, West Conshohocken.

2. Dobrzański L. (2004): Metal Engineering Materials. WNT, Warsaw.

3. Hu C. Y., Wan X. L., Wu K. M., Xu D. M., Li G. Q., Xu G., Misra R. D. K. (2020): On the Impacts of Grain Refinement and Strain-Induced Deformation on Three-Body Abrasive Wear Responses of 18Cr-8Ni Austenitic Stainless Steel. Wear, Vol. 446/447 (December 2019). https://doi.org/10.1016/j. wear.2019.203181

4. ISO. (1998): ISO 3651-2:1998Determination of Resistance to Intergranular Corrosion of Stainless Steels - Part 2: Ferritic, Austenitic and Ferritic-Austenitic (Duplex) Stainless Steels Corrosion Test in Media Containing Sulphuric Acid. 2nd Edition, Geneva.

5. ISO. (2003): ISO 17639:2003 Destructive Tests on Welds in Metallic Materials - Macroscopic and Microscopic Examination of Welds. Geneva.

6. ISO. (2005): ISO 6507-1:2005 Metallic Materials - Vickers Hardness Test - Part 1: Test Method. Geneva.

7. ISO. (2012): ISO 4136:2012 - Destructive Tests on Welds in Metallic Materials - Transverse Tensile Test. ISO, Geneva.

8. ISO. (2014): ISO 6506-1:2014 Metallic Materials - Brinell Hardness Test - Part 1: Test Method. Geneva.

9. ISO. (2016): ISO 148-1:2016 Metallic Materials - Charpy Pendulum Impact Test - Part 1: Test Method. Geneva.

10. ISO. (2016): ISO 6892-1:2016 Metallic Materials - Tensile Testing - Part 1: Method of Test at Room Temperature. Geneva.

11. ISO. (2017): ISO 15614-1:2017 Specification and Qualification of Welding Procedures for Metallic Materials Welding Procedure Test - Part 1: Arc and Gas Welding of Steels and Arc Welding of Nickel and Nickel Alloys. Geneva.
12. Jakubowski M. Corrosion Fatigue Crack Propagation Rate Characteristics for Weldable Ship and Offshore Influence of Loading Frequency and Saltw. Polish Maritime Research. 2017, Volume 24: Issue 1 DOI: https://doi.org/10.1515/ pomr-2017-0011.

13. Kozak J., Tarelko W. Case study of masts damage of the sail training vessel POGORIA. Engineering Failure Analysis. 2011, Tomy Volume 18, Issue 3, Pages 819-827, https:// doi.org/10.1016/j.engfailanal.2010.11.016.

14. Łabanowski J., Jurkowski M., Fydrych D., Rogalski G. (2017): Durability of Welded Water Supply Pipelines Made of Austenitic Steels. Przegląd Spawalnictwa, Vol. 89. https:// doi.org/10.26628/wtr.v89i8.801.

15. PKN. (2003): PN-EN 10088-1:1998/Ap 2003, Stale Odporne Na Korozję-Część 1: Wykaz Stali Odpornych Na Korozję. PKN, Warsaw.

16. Singh S., Andersson J. (2016): Review of Hot Cracking Phenomena in Austenitic Stainless Steels. 7th International Swedish Production Symposium.

17. Singh S., Hurtig K., Andersson J. (2018): Investigation on Effect of Welding Parameters on Solidification Cracking of Austenitic Stainless Steel 314. Procedia Manufacturing, Vol. 25, 351-357. https://doi.org/10.1016/j. promfg.2018.06.103.

18. Tsouli S., Lekatou A. G., Nikolaidis C., Kleftakis, S. (2019): Corrosion and Tensile Behavior of 316L Stainless Steel Concrete Reinforcement in Harsh Environments Containing a Corrosion Inhibitor. Procedia Structural Integrity, Vol. 17, 268-275. https://doi.org/10.1016/j.prostr.2019.08.036.

19. Xu D. M., Li G. Q., Wan X. L., Misra R. D. K., Yu J. X., Xu G. (2020): On the Deformation Mechanism of Austenitic Stainless Steel at Elevated Temperatures: A Critical Analysis of Fine-Grained versus Coarse-Grained Structure. Materials Science and Engineering A, Vol. 773. https://doi. org/10.1016/j.msea.2019.138722.

20. Yari M. (2017): An Intro to Pipeline Corrosion in Seawater. Corrosionpedia Vol. 2, 1432. https://www.corrosionpedia. com/2/1432/corrosion-101/an-intro-to-pipelinecorrosion-in-seawater (accessed: 29 April 2020)

21. Yin F., Yang L., Wang M., Zong L., Chang X. (2019): Study on Ultra-Low Cycle Fatigue Behavior of Austenitic Stainless Steel. Thin-Walled Structures. Vol. 143, 106205. https:// doi.org/10.1016/j.tws.2019.106205. 


\section{CONTACT WITH THE AUTHORS}

Jakub Kowalski

e-mail:jakkowal1@pg.edu.pl

Gdańsk University of Technology Narutowicza 11/12, 80-233 Gdańsk

Poland

\section{Eukasz Licznerski}

e-mail:lukasz.licznerski@crist.com.pl

CRIST S.A.

Czechosłowacka 3, 81-336 Gdynia

Poland

Milena Supernak-Marczewska

e-mail:milena.supernak@pg.edu.pl

Gdańsk University of Technology Narutowicza 11/12, 80-233 Gdańsk

Poland

\section{Krzysztof Emilianowicz}

e-mail:krzysztof.emilianowicz@pg.edu.pl

Gdańsk University of Technology Narutowicza 11/12, 80-233 Gdańsk

Poland 